\title{
The Left in Transition: The Cuban Revolution in US Third World Politics*
}

\author{
JOHN A. GRONBECK-TEDESCO
}

Abstract. This article examines the ways in which Cuba's revolution shaped the changing politics of the Left in the United States. Using critical strategies of transnationalism, it illustrates how a dialogue developed between US activists and Cuban cultural producers, and reveals how Cuba's revolutionary discourse inflected the radical shift towards Third World nationalism. As the post-Bandung global moment brought a network of new political and cultural affiliations, Cuba's state apparatus invested in the manufacture and dissemination of tricontinental politics worldwide. This alternative moral and political imaginary lent authority to Havana's status as leader of the Third World and drew global attention to Cuba's revolutionary model in new thinking on post-colonial identity and culture. This new thinking imbibed the US Left's humanistic turn which challenged standard boundaries of race, class and nation. The dialectical nature of Cuban political discourse and social activism in the United States changed Cuban exigencies while it enticed US dissidents to experience the exception in the western hemisphere that fought for the greater moral good.

Keywords: Che Guevara, Cuba, Left, Revolution, Third World, Tricontinental, United States

See, when I went to Cuba, it was like a revelation to me. Suddenly, there I was in Cuba and, at first, I didn't understand that that was real stuff, that people actually could make a revolution, that you could actually seize countries. There I was down there with a whole lot of young dudes my own age who were walking around with guns - they just did it. It blew my mind; I was never the same.

Amiri Baraka ${ }^{1}$

\section{Introduction}

Reporting in February i 959 that the Cuban Revolution was a 'people's victory', the Communist journalist, Joseph North, believed that Fulgencio

John A. Gronbeck-Tedesco is $\mathrm{PhD}$ candidate at the Department of American Studies, University of Texas at Austin. Email: johngt@mail.utexas.edu

* I should like to thank Dr. Janet Davis, the $J L A S$ editors, and two anonymous reviewers for their constructive criticism on previous drafts. Their insights helped to strengthen the paper. The librarians and researchers I met while in Havana were also of enormous help. Their patience and guidance enriched the early stages of this study, and have contributed to the cause of international scholarship.

1 Kimberly W. Benston, 'Amiri Baraka: An Interview', Boundary 2 (Winter 1978), pp. 306-7. 
Batista was rightfully overthrown by a working-class, inter-racial political bloc whose aim was to produce a new nation based on social democratic principles and progressive legislative reform. This revolution, North wrote, was for 'freedom first, and an end to the torture and terror and bloodshed suffered by the people all the long years'. North 'had the privilege of seeing the heart of a people's revolution throbbing in victory'. His mission was to deliver the significance of the Cuban triumph to his left-wing audience: 'From them I bring you this report because I want all Americans to know the truth. Not merely to know it, but to act on it, to realize our stake in it, to understand that our national honor and welfare are affected by what the Cubans did'.2

Cuba's revolutionary fervour also attracted LeRoi Jones (later Amiri Baraka) to the island. In July I960 he and civil rights renegades, Robert F. Williams, Julian Mayfield, Harold Cruse and Mae Mallory, participated in an excursion led by the Fair Play for Cuba Committee (FPCC) and hosted under Havana's 'Operation Truth'. ${ }^{3}$ For left-leaning African-Americans coming of age in the aftermath of Brown v. Board of Education, ${ }^{4}$ Cuba became the political embodiment of a new anti-racist vision; many were eager to see whether revolution could rid a society of segregation and economic disparity. Their reactions appeared in periodicals such as the Chicago Defender, Jet, Baltimore Afro-American and the FPCC bulletins. Williams became well-known in Cuba, where he published ideas about black nationalism in the Crusader and delivered jazz music and political commentary to the United States via his shortwave broadcast, Radio Free Dixie. African-American interest in Cuba grew exponentially after Fidel Castro's famous refusal to stay at the overpriced Hotel Shelburne while attending a conference at the United Nations in 1960, opting instead for the Hotel Theresa in Harlem. Castro received an enormous welcome of some 2,000 people and made time for photographs with Egypt's Gamal Abdel Nasser, India's Jawaharlal Nehru, Malcolm X,

2 Joseph North, Cuba's Revolution: I Saw the People's Victory (New York, 1959), pp. 5-7.

3 Operation Truth was an initiative that invited journalists and publicists (some of whom were FPCC members) from across the Americas to assess Cuba's revolution under the pretext of transparency. In addition to Castro's diplomatic trip to the US in April 1959, these strategies sought to bring international legitimacy to Cuba's revolutionary government while combating criticism in the United States. See Alejandro de la Fuente, A Nation for All: Race, Inequality, and Politics in Twentieth-Century Cuba (Chapel Hill, 200I), p. 296; Aleksandr Fursenko and T. Neftali, One Hell of a Gamble: Khrushchev, Castro, and Kennedy, 1958-1964 (New York, 997), pp. 5, 8.

${ }^{4}$ In 1954 the US Supreme Court decision Brown v. Board of Education made racial segregation in educational facilities unconstitutional, effectively overturning Jim Crow laws that had been authorised by the separate but equal reasoning of Plessy v. Ferguson (I 896). Brown v. Board is often viewed as a landmark decision that paved the way for further U.S. civil rights reform throughout the 1950s and i960s. 
leader of the Nation of Islam, and other representative figures of what was increasingly referred to as the 'Third World'.

This article examines the ways in which the Cuban Revolution shaped the politics of the Left in the United States in the 1960s and early 1970s. It departs from other works that focus on the Left's interest in Cuba by documenting US-Cuban developments in the formation of the 'Third World' as a people, a culture and a political project. ${ }^{6}$ What I refer to as the "postBandung global moment' bore new aesthetics and ethics in decolonised regions, which yielded a discursive cartography that privileged the ideas, history, politics and cultures of nations and groups in spaces of 'underdevelopment'. This moment can be thought of as the confluence of changing political affiliations and subjectivities, a new global 'structure of feeling', in Raymond Williams' parlance, that emerged transnationally in the aftermath of the Afro-Asian conference in Bandung, Indonesia, in 1955. The conference made matters of race, economics and nation-building high priorities among a more migratory, politicised and visible Global South. During the following decade figures such as Fidel Castro and Malcolm X became internationally recognised in a shared discourse among radicals who identified themselves with struggles of the Third World. It was a cultural formation that privileged Maoism and the avant-garde of industrialising nations, articulated and mobilised by the routes and roots of liberation movements that sought an epistemological and ontological alternative to the Cold War consensus proffered by the First World. While the 1955 conference did not directly spark world clamour for revolution, it became a foundational predecessor to the 'tricontinentalism' that formed the building blocks of Cuba's international vision. Tricontinentalism proved a top priority for Cuban leaders and taste-makers who wanted to establish a geopolitical and moral alternative that united Asian, African and Latin American peoples against the US-led West and its sordid prescriptions for economic development, modernisation and governance. The tricontinental was formed in the legacy of Bandung's geographical and political remapping. Havana offered a model of liberation to be followed internationally, with Cubans creating new cultural

5 Besenia Rodriguez, 'Beyond Nation: The Formation of a Tricontinental Discourse', PhD diss., Yale University, 2006, pp. I I-6; Alejandro de la Fuente, A Nation for All: Race, Inequality, and Politics in Twentieth-Century Cuba (Chapel Hill, 200I), pp. 296-9; Timothy Tyson, Radio Free Dixie: Robert F. Williams and the Roots of Black Power (Chapel Hill, I 999), p. 232-5; Van Gosse, 'The African-American Press Greets the Cuban Revolution', in L. Brock and D. Castañeda Fuertes (eds.), Between Race and Empire: African-Americans and Cubans before the Cuban Revolution (Philadelphia, I 998), pp. 266-80.

${ }^{6}$ I borrow the notion of the Third World as a 'political project' from Vijay Prashad, The Darker Nations: A People's History of the Third World (New York, 2007). 
industries that informed debates over revolution and resistance in the United States.

Cuba's state apparatus constructed, promoted and disseminated cultural works and social ideas that remained central to the trajectory of US Left politics. US-Cuban exchange assumed a dialogical nature, unveiling the dynamism and competing ideologies of politics and form that flowed across the Florida Straits. Rather than viewing Cuba as a static cultural or national entity, interpellated and defined by a dynamic US society, this analysis demonstrates how Cuba, too, underwent change in this period, and was also influenced by the work of northern radicals. As US civil rights and feminist organisations brought new voices, goals and demands, so too did the meaning of Cuba's revolution change. If members of the US Left were galvanised by the allure of Cuba's revolution, then equally important were the ways in which the Cuban state - hoping to grow in international legitimacy and influence - retooled its own national programme, enticing young North American radicals to experience the exception in the western hemisphere that fought for the greater moral good.

This discussion begins by outlining early interest in Cuba by an inchoate New Left, showing the cultural appeal of the 'people's revolution'. It then moves to reveal how and why revolution functioned in the US radical imaginary during the discursive shift to Third World resistance by the end of the decade. Revolution continued to hold symbolic power in Left politics, well after its cachet had faded following the failed Bay of Pigs invasion and the Cuban Missile Crisis, as the New Left began to splinter and fray. This section focuses on the earlier Bandung Conference and its impact on Cuba's revolution, and the subsequent global reverberations of Third World politics that were heard in the United States around issues of race, gender and postcolonial identity. Revolution helped to generate a broad-based identification among multiple ethnic nationalisms, which coalesced around the liberation of the oppressed and a rejection of white Western culture. It shaped the black power politics of Stokely Carmichael and the feminist humanism of Angela Davis, and played a vital role in the emergence of a US Third World Left that turned to Cuba for alliance and inspiration. The paper ends with a scrutiny of the significant - if disproportional - weight afforded to Che Guevara in left-wing discourse, and offers some suggestions on how his location in the US-Cuban dialogic may be useful for contemporary conversations on theorising the transnational.

\section{Revolutionary Culture and the Building of a New Left}

The US Left's well-known 'romance' with the Cuban revolution began in the late i950s. As news of Cuba's Revolution made headlines, US society was 
gripped by fidelismo. ${ }^{7}$ Students, journalists, professors and activists eagerly offered first-hand observations of Cuba, which stood as a model exemplar in the new zeitgeist that promised social reorganisation and political potency of the people. Searching for participatory democracy and fuelled by a utopian impulse with existential meaning and political direction, the new bloc found Cuba an avenue through which to throw off the shackles of apathy and alienation. Chief among revolutionary enthusiasts was C. Wright Mills, the iconoclastic academician known for his maverick intellectualism and mid-life motorcycle manhood. Mills was part of a growing coterie of intellectuals, disillusioned by anti-communist red-baiting, who actively challenged Cold War liberalism in matters of economics, social welfare and US foreign policy.

Even before the Port Huron Statement of 1962, Mills had outlined some principles of the New Left in his foundational call to arms, 'Letter to the New Left', in which he dismissed the 'end-of-ideology' argument as a 'slogan of complacency' and deemed liberal apologists lackeys of anti-communist paranoia. ${ }^{8}$ For Mills, one could choose sides in matters of political praxis: 'The Right, among other things, means - what you are doing, celebrating society as it is, a going concern. Left means, or ought to mean, just the opposite. It means: structural criticism and reportage and theories of society, which at some point or another are focussed politically as demands and programmes'. 'To be "Left"', he continued, 'means to connect up cultural with political criticism, and both with demands and programmes ... If there is to be a politics of a New Left, what needs to be analysed is the structure of institutions, the foundation of policies. In this sense, both in its criticisms and in its proposals, our work is necessarily structural - and so, for us, just now - utopian'.

A trip to Cuba inspired Mills' quite popular Listen Yankee! ( I960), which used the voices of Cuban revolutionaries to mark clearly the division between the antiquated Old Left that praised Soviet politics and the new generation:

Since we did not belong to the old left intelligentsia - the older men who had gone through Communism and been disillusioned with Stalinism and with the purges and

7 Van Gosse, Where the Boys Are: Cuba, Cold War America, and the Making of a New Left (New York, i993), p. I.

8 The Port Huron Statement was a document that emerged from a Students for a Democratic Society (SDS) meeting in Port Huron, Michigan, in 1962. Many historians of the Left consider it to be the founding manifesto of the US New Left that concretely spelled out the sense of political dissatisfaction and alienation felt among young people and the desire to change social structures using direct action in university settings. For the full text, see http://coursesa.matrix.msu.edu/ hst306/documents/huron.html (accessed 28 July 2008).

9 C. Wright Mills, 'Letter to the New Left', New Left Review, no. 5 (Sept.-Oct. i960), pp. I 8-23. Emphasis in the original. 
the trials and the 35 years of all that-we've had one enormous advantage as revolutionaries... We are revolutionaries of the post-Stalin era; we've never had any "God That Failed"... We are new men... We are new radicals. We really are, we think, a new left in the world. ${ }^{\mathbf{1 0}}$

Pilgrimages to Cuba inspired books, pamphlets and essays that verified Cuba's success in human development and economic engineering. Paul Baran, then a professor of economics at Stanford, relished Cuba's progress: 'We walked through abysmal quarters of Santiago de Cuba where hovels, the horror and sordidness and misery of which are beyond my power of description, are being torn down and replaced by entire streets of light, clean, colorful little houses'.11 Leo Huberman and Paul Sweezy's Cuba: Anatomy of a Revolution (I960) also remained a popular book. The authors held Cuba's revolution to be 'one of the most original and important social transformations of our time'. Cuba's visual mosaic of cigar-smoking, bearded revolutionaries who were transforming a country amidst popular jubilation, garnered approbation from a world audience in its staunch rejection of US hegemony. It stood as a symbol of an alternative order, which the authors believed would hasten a 'brighter socialist future'. ${ }^{12}$ Academic journals such as Studies on the Left agreed, and declared the Cuban revolution 'the most important and least understood social development in the recent history of the Western Hemisphere'. ${ }^{13}$

Intellectuals and artists also found Cuba's political redesign amenable for new thinking on revolutionary culture. Cuban leaders posited revolution as necessary and nurturing for cultural development in the decolonised world. Armando Hart, the Minister of Education, made it clear that revolution brought a new cultural apparatus that replaced 'bourgeois interests'. Now the objective was to 'create the conditions of social organisation, environment, and of popular consciousness, so that new cultural forms, products of the present process towards a socialist society, are manifested in all of their force, and proceed with the incorporation of new expressive forms in our cultural legacy'. Culture was viewed as epiphenomenal of economic processes; different class relations and state planning meant changes in production, distribution and exchange, as well as cultural proclivities that led to new aesthetics and tastes and the reorganisation of cultural industries. ${ }^{\mathbf{1 4}}$

${ }^{10}$ C. Wright Mills, Listen, Yankee: The Revolution in Cuba (New York, I960), p. 43. For more on Mills and Cuba, see Gosse, Where the Boys Are, pp. I76-83.

11 Paul Baran, Reflections on the Cuban Revolution (New York, I96I), p. 5.

12 Leo Huberman and Paul Sweezy, Cuba: Anatomy of a Revolution (New York, 1960), Preface, and p. 173 .

13 Studies on the Left, vol. I, no. 3 (1960), p. I.

14 Armando Hart, 'Palabras al Congreso Nacional de Cultura', Casa de la Américas (March-June 1963), pp. 3-6. 
Cuba's Casa de la Américas was a cultural salon, museum and international publication that showcased artists, politicians and intellectuals who appeared in conferences, performances and essays under its auspices. The Casa created a cultural space for revolutionary creativity, which privileged the avant-garde as well as the multiple realities of the 'Third World'. Argentine writer Julio Cortázar confirmed the importance of revolution in creative endeavours: 'It is evident that the possibilities revolution offers a storyteller are almost infinite. The city, the country, struggle, work, the distinct psychological types, the ideological and character conflicts; all is exacerbated by the desire to act, express oneself, and to communicate like you hadn't been able to before'. ${ }^{\mathbf{1 5}}$ Cuba beckoned poets and folk singers from the United States as well, driving a thorn deeper in the State Department's side while reinforcing the image of Havana as a welcoming place for artistic experiment. Pete Seeger visited Cuba and received a warm welcome, and thoughts of Cuba later inspired Judy Collins's folksy lament for the death of Che Guevara entitled Che. ${ }^{\mathbf{1 6}}$ Beat poet Lawrence Ferlinghetti remembered meeting Pablo Neruda and Fidel Castro, and noted the 'fantastic throbbing atmosphere' and the 'revolutionary euphoria' in Havana. Such artists were welcome to the vibrant scene as long as their views found commonality with Cuba's new political vision. ${ }^{17}$

LeRoi Jones was also profoundly affected by his Cuban experience. His I960 trip was a watershed moment in his political development. Jones delivered his impressions of Cuba in the widely circulated 'Cuba Libre', which first appeared in the November/December I960 issue of Evergreen Review. His report placed the reader in a frenetic environment of thousands of fidelistas chanting 'Cuba Sí, Yanqui No' while on a pilgrimage to Santiago de Cuba, where Castro and the 26th July Movement had declared victory the year before. The 25-year old Jones was openly overwhelmed by the brouhaha which stirred up questions about political efficacy in his home country: 'What was it, a circus? That wild mad crowd. Social ideas? Could there be that much excitement generated through all the people? Damn, that people still can move. Not us, but people. It's gone out of us forever. "Cuba, Sí. Yanqui, No.",18

The Beat poet remembered that the idea of revolution had been 'one of those inconceivably "romantic" and/or hopeless ideas that we Norteamericanos have been taught since public school to hold up to the cold light

15 Julio Cortázar, 'Algunos aspectos del cuento', Casa de las Américas (November I 962-February i 963), p. I 2.

16 Lionel Martín, 'Pete Seeger, el cantante de la libertad', Cuba internacional (May 1971), pp. 50-3.

17 Lawrence Ferlinghetti, interview by Amy Goodman, Democracy Now, 3 September 2007.

18 LeRoi Jones, Cuba Libre (New York, i961), pp. 3, 5. 
of "reason." Indeed, Jones reduced the political impulse among young people in the United States to faddishness: 'The rebels among us have become merely people like myself who grow beards and will not participate in politics. A bland revolt. Drugs, juvenile delinquency, complete isolation from the vapid mores of the country - a few current ways out'. ${ }^{19}$ Shortly after his trip, Jones composed 'Betancourt', a poem inspired by a Mexican Communist who had seen Jones as nothing more than 'a petit bourgeois poet'. Her jabs at his political apathy distressed him, and yielded the first lines of the poem, which read:

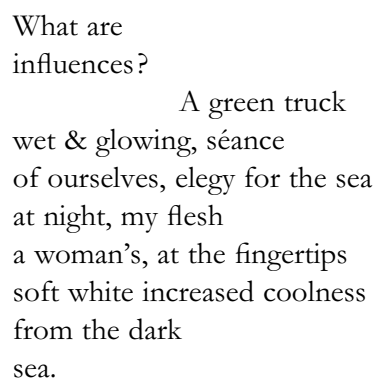

The subsequent stanzas evoked images of an erotic escapade with racial undertones, devoid of obvious political content. But more important is that between the verses of 'Betancourt' and the prose of 'Cuba Libre' lay a Jones in transition from apolitical Beat to Third World revolutionary, from Jones the editor of Yugen magazine to Amiri Baraka, the leading figure in the Black Arts Movement. The Cuban experience did not change Jones's political compass singlehandedly, but it remained a powerful ingredient in his evolution as an artist and political thinker. It also represented the seeds of a greater transformation taking place in US Left politics. ${ }^{20}$

Baraka called Cuba 'a trigger' for his embrace of pan-Africanism, which focussed on creating an autochthonous black cultural order while holding high regard for leaders such as Guinea's Sékou Touré and Ghana's Kwame Nkrumah. 'The Africa thing had been developed previous to that', he recalled, 'but the Cuba thing popped the whole thing open, because once I went there and then got the whole feeling of the whole international correspondence, of motives and actions and ideologies, I was changed, you know? In a deep way. Because I had been inherently trying to get political,

19 Jones, Cuba Libre, p. I 5 .

20 Cynthia Young provides ample evidence for this argument as well: see her Soul Power: Culture, Radicalism, and the Making of a U.S. Third World Left (Durham, NC, 2006), pp. 3 I-7. Benston, 'Amiri Baraka', p. 307; 'Betancourt', in Paul Vangelisti (ed.), Transbluesency: The Selected Poems of Amiri Baraka/LeRoi Jones, 196I-1995 (New York, I995), pp. 37-4I ; Jones, Cuba Libre, pp. 4-5. 
but that was the stroke, because it showed me that there was a whole world that was in motion'. ${ }^{21}$ Diasporic politics strengthened racial activism, eventually fuelling developments in the attention that Baraka and others paid to Third World culture. Cuba's revolution nurtured these connections by representing a 'black nation' trenchantly assertive in its own liberation and one that took race seriously in political discourse. Cuba's state apparatus aggressively pursued a position of leadership in the decolonised world, which placed race front and centre in campaigns of revolution and liberation in its formulation of the tricontinental.

\section{Cuba in the Post-Bandung Global Moment}

Cuba's role in the discursive shift in US Left politics from 'alienation' and 'anxiety' to Third World nationalism must be understood within the wider political and social landscape of decolonisation. A new conjunctural moment was highlighted in April i955, when leaders from 29 African and Asian countries gathered in Bandung in Indonesia to concentrate on the problems of uneven economic development, war, human rights, nuclear proliferation, colonialism and global racism. In the wake of Dien Bien Phu, but before the liberation of Algiers, ${ }^{22}$ the conference created a staging ground for nonaligned nations to seek an alternative order to the bivalent East-West and to narrow the gap between the North and South. Most states were bonded by a shared post-colonial condition, and attendees issued support for plans that discussed topics not addressed by the United States or the Soviet Union and their allies. ${ }^{23}$

Nearly eleven years later leaders in Havana positioned Cuba as the torch bearer of the post-Bandung world. In January i966, Cuba convened the inaugural meeting of the Organisation of Solidarity of African, Asian and Latin American Peoples (OSPAAAL). ${ }^{24}$ The conference brought 483 delegates from 82 countries to Havana, its mission being 'to increase the antiimperialist battle on the three continents'. ${ }^{25}$ Representatives discussed

21 Van Gosse, 'Home Rules: An Interview with Amiri Baraka', Radical History Review, no. 87 (2003), p. II

22 The French defeat at the battle of Dien Bien Phu in 1954 signaled a victory for the Viet Minh and the ensuing decline of France's colonial possessions in Indochina. Eight years later the French were defeated in Algiers, which secured Algerian independence. These two occasions marked monumental moments in the era of decolonisation.

${ }^{23}$ G. McTurnan Kahin, The Asian-African Conference (Ithaca, 1956); Carlos Rómulo, The Meaning of Bandung (Chapel Hill, 1956).

24 Tricontinental is the journal produced by OSPAAAL.

25 'A dos años de la primera conferencia Tricontinental', Tricontinental (January-February I968), pp. 3-I 2. 
nationalist movements in Africa, Asia and Latin America, with sharp rebuke reserved for US involvement in Vietnam and the spread of US-inspired capitalism. The gathering proposed to resuscitate the spirit of Bandung, but its Cuban hosts concentrated on expanding the bicontinental framework to encompass the tricontinental. ${ }^{26}$ OSPAAAL highlighted the importance of Latin America in the Third World and positioned Cuba as the leader of revolutionary thinking and action. Cubans asserted that 'in Asia, Africa and Latin America the Cuban Revolution has captured the heart and imagination of the exploited classes, and the triumph of January I, 1959, the culmination of the heroic process initiated with the assault on the Moncada fortress on July 26, I953, is a historical event charged with significance for all liberation movements'. Cuba was a model to be followed, observed and emulated. 'Solidarity with Cuba', wrote one Cuban journalist, 'is the best defence that the people have, particularly in Latin America, in their fight against today's enemy of progress and liberty, North American imperialism..27

Tricontinentalism became fundamental to Havana's geopolitical strategy and rhetorical leverage in the international arena. It offered an alternative political programme and list of economic remedies that differed from those presented by the United States, western Europe, and the International Monetary Fund. The counter-discourse challenged the modernisation strategies and anti-communist politics prescribed by the 'Free World', and projected a language of liberation and nationhood for the deterritorialised and decolonised. In one of his last official communiqués in 1967, Che Guevara situated Vietnam as a benchmark for the Third World, but maintained that the America of José Martí stood at the helm of this resistance, with Cuba its captain: 'America, a forgotten continent in the last liberation struggles, is now beginning to make itself heard through the Tricontinental and, in the voice of the vanguard of its people, the Cuban Revolution will today have a task of much greater relevance: creating a Second or a Third Vietnam ... of the world ${ }^{28}$ Che and other Cuban officials proselytised tricontinentalism in speeches and conferences in an effort to build solidarity among African, Asian, and Latin American peoples towards the common goal of defeating US military and economic expansion. ${ }^{29}$

26 'Antecedentes y objetivos del movimiento de solidaridad de los pueblos de Africa, Asia, y América Latina', Cuba socialista (February i966), pp. 45-6.

27 'Cuba: Una respuesta adecuada en América Latina', Tricontinental (July i 968), pp. 3, 5.

${ }^{28}$ Che Guevara, "Message to the Tricontinental: "Create two, three ... many Vietnams", in John Gerassi (ed.), Venceremos! The Speeches and Writings of Ernesto Che Guevara (New York, I968), p. 420.

29 Che Guevara, 'On Our Common Aspiration - The Death of Imperialism and the Birth of a Moral World', in Gerassi (ed.), Venceremos, p. 378. 
This authority derived, in part, from the assertion that Cuba was now a nation where racism had officially ceased to exist. ${ }^{30}$ 'Third World' was also read as 'non-white', in such a way that Cuban prestige depended on the image that all Cubans lived in socially equal conditions, irrespective of race and without class. Social barriers were said to have been eviscerated with the vanquishing of the bourgeoisie in 1959; socialism had caused institutionalised racism to disappear naturally. The revolution, many maintained, had 'eliminated from Cuban life the odious and humiliating spectacle of discrimination by colour of skin'. ${ }^{31}$ The world saw that Afro-Cubans now had access to public spaces hitherto reserved for whites. Night clubs and beaches were now desegregated, and blacks enjoyed state-supported education and occupied higher professional positions. Antonio Maceo and Nicolás Guillén became celebrated Afro-Cuban heroes, and the ordinary black subject was elevated to popular memory, with black resistance now included in mainstream historical accounts. The notion of a racially equal Cuba emerged in multiple cultural forays across the island. The film Realengo I8 (I96I) used black actors to portray the armed peasant struggle against the US-backed Cuban government in the I930s. Also popular was Miguel Barnet's Biografía de un cimarrón (1966), a book that told the story of 105-yearold ex-slave, Esteban Montejo, and his life of struggle first against slavery and later against Spain in the War of Independence. Both Realengo and Biografia proved that Cuban heroes could be any race and of any class standing. Cuba exported new statistics, narratives and policy initiatives that remade its usable past and substantiated the belief that Cubans were now colour blind. ${ }^{32}$

Havana's new global presence included foreign policy that reflected the new racial logic. Arms, aid, and troops arrived in countries throughout Africa and Latin America. Cuban revolutionary initiatives were strengthened with a massive exportation of cultural initiatives that included literature dedicated to intellectualism, art and revolution. ${ }^{33}$ Joining Casa de las Américas was Tricontinental, an international magazine that published articles on Cuban foreign policy, poems, social essays, and reports on major events in the 'developing world'. Distributed in French, Arabic, English and Spanish, it reached a worldwide audience and served to unite opposition against the United States and its allies. Subscribers would find articles on North Vietnamese resistance, vignettes on class struggle in India, and news of Palestinian and Syrian confrontations against Israel. Readers would learn

30 De la Fuente, $A$ Nation for $A l l$, p. 4.

31 José Felipe Carneado, 'La discriminación racial en Cuba no volverá jamás', Cuba socialista (Jan. 1962), pp. 53-67.

32 De la Fuente, $A$ Nation for $A$ ll, p. 288.

${ }^{33}$ For more on Cuba's interest in Africa, see Piero Gleijeses, Conflicting Missions: Havana, Washington, and Africa, 1959-1976 (Chapel Hill, 2002). 
from an up-and-coming Yasser Arafat that Palestinians 'have great confidence in our friends in Cuba' ${ }^{34}$

To strengthen claims that Cuba was socially advanced, Cuban cultural workers focused on the problems of the civil rights movement in the United States, covering racial strife in Montgomery, Greensboro and Selma. Readers around the world encountered news on racial violence, 'from Little Rock to urban rebellions', as well as the coalitional work of the Black Panthers, Brown Berets and Young Lords. Following the explosion of ethnic and racial radicalism in the United States, Cubans published excerpts from Stokely Carmichael's and Charles Hamilton's book, Black Power (1967), as well as an address by H. Rap Brown of the Student Nonviolent Coordinating Committee (SNCC). ${ }^{35}$ At New York City's Village Theater, Brown talked about 'Vietnam and Black America', in which he connected war in Vietnam with the oppression of blacks around the world. Across the Florida Straits, Cubans read the messages of Brown and other African-American leaders, which were deemed crucial in what one Cuban writer called 'the awakening of the Third World that began in Bandung and that culminates in Havana'. Cuban elites urged 'the Afro-American masses to strengthen their united action' and promised that Cuba was 'fully conscious of the importance of their struggle, since they fight Yankee imperialism from within while [Cubans] dismember it from afar'. ${ }^{36}$ Exposing racism in the United States was a political imperative for Cuba's geopolitical strategy and served to build national cohesion. Projecting the United States as immoral and hypocritical in its democratic experiment exposed an obvious sore spot on Uncle Sam's record of liberty and prosperity, such that April i96 I brought news of the failed Bay of Pigs invasion as well as recent racial terror by the Ku Klux Klan and memories of Emmett Till. ${ }^{37}$ Cuba, by contrast, could offer a societal antidote that made strides where the United States lagged.

34 'Indochina: La respuesta efectiva a la agresión Yanqui', Tricontinental (July-Aug. 1970), pp. 9-19; 'India y la lucha de las clases', Tricontinental (Feb. 1970), pp. 25-37; Osvaldo Ortega, 'Palestina: La revolución del pueblo', Tricontinental (September I97 I), p. 35.

For more on Black Power politics in the United States, see Komozi Woodard, A Nation within a Nation: Amiri Baraka (LeRoi Jones) and Black Power Politics (Chapel Hill, 1999); Peniel Joseph (ed.), The Black Power Movement: Rethinking the Civil Rights-Black. Power Era (New York, 2006); Jeffrey O. G. Ogbar, Black Power: Radical Politics and African American Identity (Baltimore, 2004).

36 'USA: de Little Rock a las rebeliones urbanas', Tricontinental (January 1970), pp. 7-16; Lisandro Otero, 'Racismo, segregación y poder negro en Estados Unidos', Revolución y cultura, is April I968, pp. 2-4; Claude Julien, 'Malcolm X y los Black Muslims', Revolución y cultura, is April 1968, pp. I6-29; H. Rap Brown, 'Viet-nam y la Norteamericana Negra', Revolución y cultura, is April i968, pp. I I I-7; 'Estados Unidos: Confrontaciones armadas', Tricontinental (Oct. 1969), p. 32.

${ }^{37}$ Fulton D. Namyte, 'El siniestro Ku-Klux-Klan', INRA (April I96r), pp. 40-3. 
As Amiri Baraka recounted, Cuba evinced a connection to Africa in a way not felt in the United States. After I 959 Cubans, too, read C. L. R. James's thoughts on 'Black Power' as well as expressions of 'Africa in America' that showcased black Atlantic philosophers like Nicolás Guillén, Aimé Césaire, W. E. B. Du Bois, Jacque Roumain, Frantz Fanon and Malcolm X. The turn to 'Afroamerica' was important in popular discourse, and most AfricanAmerican visitors to Cuba were impressed with the wider participation of Afro-Cubans in higher social capacities. Race in Cuba's national discourse was connected to the notion of cultural hybridity. The mulatto remained the most powerful trope of the Cuban nation, as it had since the days of José Martí. The mixture of black and white, African and European, made one Cuban writer affirm that 'the mulatto sentiment of homeland will also determine Cuban ethnic liberation, not only in the racial sense, but also in the national'. In fact, biracial identity in a sense made a raceless republic, for a nation that is both black and white is also neither black nor white. Cubans were to be mindful of European and African cultural antecedents but also to remember, 'we are not Africa, like we are not Europeans: we are America, our America'. ${ }^{38}$

While the new nationalism trumpeted claims to racelessness and racial equality, revolution did not make racism ethereally disappear from Cuba. Institutionalised discrimination was largely dismantled, but historicallyentrenched racist social norms continued in unmediated ways, with university attendance, government positions and media professions occupied mostly by white applicants. Race continued to be a determining factor in power and privilege. Economically, black Cubans laboured disproportionately to make ends meet, and socially many whites proved uncomfortable with the prospect of sharing public spaces with blacks. White privilege continued to dominate the lives of everyday Afro-Cubans, so that despite gaining in areas such as sports and music, black Cubans still encountered racism in matters of work, marriage, and standards of beauty. And despite Afro-Cubans' indispensable contributions to the anti-Batista resistance, most of the revolutionary heroes such as Che, Fidel and Camilo Cienfuegos were white. ${ }^{39}$

\section{'Ser como el Che': Cuba, Post-Coloniality and the US Third World Left}

The 'reality' of Cuba's complex racial landscape did not preclude its symbolic power in the radical imagination of the north. The island's leading

${ }^{38}$ C. L. R. James, 'Poder Negro', Casa de las Américas (May-June i 968), pp. 2-I 5 ; 'Africa en América', Casa de las Américas (May-August i 966), pp. 3-4; Elías Entralgo 'La mulatización cubana', Casa de las Américas (May-August i 966), pp. 76-80.

39 De la Fuente, $A$ Nation for All, pp. 26o-85; Elizabeth Sutherland, The Youngest Revolution: $A$ Personal Report on Cuba (New York, 1969), pp. I49-68. 
position in the post-colonial world meant a relentless challenge to the democratic creed of the United States and the promotion of Cuba as the panacea to the social ills that plagued US towns and cities. Cuba remained a political Mecca for Yankee dissidents. Cuba's revolutionary cartography brought a catalogue of images and representations that contributed to the US Left's shift to the 'Third World'. According to the cultural historian, Cynthia Young,

The US Third World Left was forged in the interstices between the New Left and Civil Rights, between the Counterculture and the Black Arts movement, between domestic rebellion and international revolution. A generation of African-American, US Latino/a, and US Asian artists, intellectuals and activists created cultural, material and ideological links to the Third World as a mode through which to contest US economic, racial and cultural arrangements. ${ }^{40}$

Out of the coalitional work by people of colour and the global uprisings in Prague, Paris and Mexico City emerged an international language of dissent that criticised US empire, global racism, political repression and economic underdevelopment. These included transnational debates over race, culture and identity of the marginalised and oppressed, which proposed a new community of resistance against white regimes of power. Cuba's tricontinentalism imbibed understandings of black nationalism and helped fuel the emergence of a left humanism in which an identification with anti-capitalism, anti-imperialism and anti-racism broke myths about cultural, racial and national authenticity. ${ }^{\mathbf{4 1}}$ Cuba established an international forum for new questions of non-white identity and class warfare in the United States, which challenged standard epistemological and ontological assumptions of the Third World, and which remained a pivotal point for US activists whose cultural politics remained distinct from the white capitalist West.

Stokely Carmichael (later Kwame Ture) found Cuba's tricontinental vision relevant for his identification with the African diaspora. SNCC's former leader underwent a dramatic change in consciousness (highlighted by his controversial utterance of 'Black Power') that ultimately positioned diaspora as a way to wage cultural politics. Carmichael called culture 'a cohesive force' and viewed all descendants of the African diaspora as 'Africans' in search of new values, new societies, with the ultimate goal 'to stop all influence of

${ }^{41}$ Here I draw from Besenia Rodriguez's notion of tricontinentalism, which signified a political alignment of US activists who employed anti-essentialist definitions of race and nation in order to forge a universalist vision based on anti-capitalism, anti-racism and antiimperialism: Rodriguez, 'Beyond Nation', pp. iv-viii. 
Western culture on our people - completely,. ${ }^{42}$ While at a London conference on Black Power, Cuban representatives convinced Carmichael to visit Havana, which became a capstone experience in his political development:

It was an incredible moment, more than just exciting. It was eye-opening, inspiring and mind-blowing. I mean, here were brothers and sisters from around the whole world, Jack, especially the 'third world', who were struggling to liberate humanity from colonialism, economic exploitation, and the absurd and pernicious principle that corporate profit, individual selfishness and greed can be an effective basis for social organization and decent human interaction.

The Cuban experience helped Carmichael frame the struggles of African Americans and Latin Americans in common terms under the 'American' appellation, both groups anchored with qualifying adjectives that discursively allied them in their opposition to US whiteness. For Carmichael, both were 'oppressed by the same forces - capitalism and gringo imperialism - and thus share[d] the same struggle'. The rhetorical turn conjoined black North Americans and Latin Americans in challenging standard notions of a white 'American' identity and politics, and showed that diasporic politics and panAmericanism could align along a common counter-hegemonic axis that included Mississippi, Harlem and Havana. ${ }^{43}$

Such desire was not without its own exclusionary principles. The fight against 'gringo imperialism' often promoted a revolutionary resistance that glorified projections of masculinity. Cuban manhood became a dominant image associated with racial politics in the United States, the 'New Man' a trope that signified the ideal Cuban citizen and the optimum Third World revolutionary. It produced the belief that the new man was 'simple, politically and scientifically responsible, with an unbreakable conscience of his patriotic and human duties' and that 'the formation of the new man is the central concern of the Cuban revolution and its leader, Commandant Fidel Castro'. Revolutionary manhood was connected to the liberation of Third World peoples and became a central component to black nationalism. The co-founder of the Black Panthers, Huey Newton, called the optimal soldier 'an exceptional man' who combined military might with intelligence and a sense of justice, in line with Che's formulation of the theory-minded guerrilla fighter. Newton and others reiterated praise for Guinea's Sékou Touré, the Congo's Patrice Lumumba, and Ghana's Kwame Nkrumah. They were leaders who inspired brazen effrontery to the white West, and their popularity

42 Stokely Carmichael, 'Pan-Africanism - Land and Power', in William Van Deberg (ed.), Modern Black. Nationalism: From Marcus Garvey to Louis Farrakhan (New York, 1997), p. 2 I 3.

43 Stokely Carmichael with Ekwueme Michael Thelwell, Ready for Revolution: The Life and Struggle of Stokely Carmichael (New York, 2003), pp. 582-8. 
lent credence to the assertion that national liberation was a male-dominated affair. $^{44}$

Fidel Castro entered the pantheon of manly Third World leaders. Eldridge Cleaver's bestselling book, Soul on Ice (1968), was, among other things, a treatise on masculinity, in which Castro, Mao and Ben Bella represented nonwhite male heroes who could effectively thwart a James Bond or Lyndon Johnson. ${ }^{45}$ These connections stemmed from a racial politics that made 'blackness' or 'brownness' more than a phenotypic signifier, but a political mindset from which to wage praxis. Vijay Prashad has written that in the United States 'black' was a political colour, which could explain Stokely Carmichael's one-time quip that Fidel Castro was 'one of the blackest men in America ${ }^{, 46}$ While whites remained part of the movement to embrace the 'underdeveloped' world, whiteness, along with imperialism and capitalism, was deemed a social barrier that continued to dominate the subaltern psychologically, territorially and economically. Castro's maverick anti-US stance, therefore, commanded attention in the new political discourse, which brought comparisons between Fidel and black public figures. Eldridge Cleaver likened Castro's military acumen to Mohammed Ali's robust boxing credentials, calling Ali the 'black Fidel Castro of boxing' who defeated his opponents as Castro did at the Bay of Pigs. 'If the Bay of Pigs can be seen as a straight right hand to the psychological jaw of white America, then Las Vegas was a perfect left hook to the gut'. ${ }^{47}$ Echoing Carmichael's commensuration of African and Latin Americans, Cleaver suggested that Ali and Castro stood as a heavyweight duo united in their confrontation of white political structures. What Castro did on the battlefield, Ali did in the ring; violent resistance depended on manliness and multiracialism, which could conquer opponents while it reinforced non-white heterosexual manhood.

Tricontinental brotherhood, therefore, could be quite explicit in its misogynistic attitudes towards women and disparagement of male homosexuals. Cleaver argued that writer James Baldwin represented the negation of the black male revolutionary, whitened and weak due to his homosexuality and

${ }^{44}$ For more on the revolution's impact on manhood in the United States, see Gosse, Where the Boys Are. Interview with Huey Newton, 'Poder Negro y lucha revolucionaria', Tricontinental (November 1968), pp. 5-12; 'A dos años de la primera conferencia Tricontinental', Tricontinental (January-February i 968$)$, p. i 8.

45 Eldridge Cleaver, Soul on Ice (New York, i 968), p. 82.

46 Quoted in Vijay Prashad, Everyone was Kung Fu Fighting: Afro-Asia Connections and the Myth of Cultural Purity (Boston, 200I), pp. 5 I-2.

${ }^{47}$ Cleaver is making a comparison between Ali's renegade status as a boxer and Castro's revolutionary leadership in Cuba. The allusion is to Ali's I965 victory in Las Vegas over Floyd Patterson, who for Cleaver represented the counterrevolutionary in the match, the favored of white America (though Patterson was black). Ali's win, therefore, threatened white US power as did Castro's victory at the Bay of Pigs. Cleaver, Soul, pp. 92-3. 
attraction to 'bourgeois culture' and (white) men. This intersection of class and sexuality echoed Cuban popular discourse, which dodged the topic of homosexuality while it remained abundantly critical of bourgeois tastes. The case of Cuba therefore ratified the imagined community constructed by Cleaver and other male leaders of the Third World Left that limited women and omitted homosexuals from the discursive domain of revolutionary politics. ${ }^{48}$

In Cuba, women were deemed central to the revolution's success, but equality between the sexes was not achieved to the same degree as it was promoted. Like racism, sexism was said to have been eliminated under socialism. Some norms did reflect a new equal footing between men and women. Lower income women now enjoyed access to a greater range of jobs, and from the early i 970 s men were designated by law to be equally responsible for the care of children and the home. But many prerevolutionary gender roles remained intact, with the result that women were still expected to take charge of domestic duties while attending to work outside the home in service to state and society. ${ }^{49}$

Amid the variable realities of Cuba's gendered terrain was the move by certain members of the Third World international to challenge such patriarchal projections of power. Early displays of third-wave feminism debunked claims to male revolutionary authenticity, and in doing so reshaped the mould of Cuban tricontinentalism as well. One student group expressed its desire to 'join hands with our Cuban brothers and sisters in the struggle against US imperialism and for the construction of a society of the new man and new woman'. ${ }^{50}$ Angela Davis and Elizabeth Sutherland Martínez were examples of leading Left figures whose feminist politics challenged conventional thinking on gender and revolution. An influential figure in California's Chicana/o movement, Sutherland (later Martínez) travelled to Cuba with SNCC in 1967. Sutherland's model of the socialist Third World included equal contributions by both men and women. She saw Cuba's New Man as a fading figure, acknowledging that revolutionary Cuba was not exclusively a male world, for 'no longer were women the janitors, caretakers, and consumers of the society, but its producers and organizers'. Yet she begrudgingly concluded that the New Man continued to overshadow the New Woman, for 'machismo still had a firm grip'. ${ }^{51}$

48 Cleaver, Soul on Ice, pp. 92-3, 10 I-03, I 88-92.

49 Muriel Nazzari, 'The "Woman Question" in Cuba: An Analysis of Material Constraints on its Solution', Signs, vol. 9, no. 2 (Winter 1983), pp. 246-63.

50 'The Political Purpose of La Brigada Venceremos', Brigada Venceremos Bulletin, May I971, pp. 8, I4-1 5. My emphasis.

51 Sutherland, The Youngest Revolution, pp. 97-100, 170-90. 
Angela Davis also questioned androcentrism in her revolutionary resistance and found Cuba an inspiring environment. In 1969, she proclaimed Cuba's experiment a success: 'They were finished with the politics of class and race, done with the acid bile of outdoing one's neighbor for the sake of materially rising above him'. Davis remembered her trip as 'the great climax in my life ... politically I felt infinitely more mature, and it seemed that the Cubans' limitless revolutionary enthusiasm left a permanent mark on my existence, ${ }^{52}$ In 1970 Davis appeared on the FBI's Top Ten Wanted list for her distant association with the kidnapping and death of a judge in a failed prisoner escape (one of the weapons used was registered in her name). While in prison, the fight to Free Angela Davis quickly became a global cause against racism and political imprisonment. Cubans participated in the international campaign and believed the Davis case symbolised 'the clear and just revolutionary battle within the United States, particularly the struggle by Afro-Americans for a full and dignified life'. Davis's popularity placed women in the centre of Cuban tricontinental dissent, and her efforts made radical women active participants in, rather than passive recipients of, political gains won by oppositional work. The voices of activist women of colour were heard in Cuba, where calls to celebrate 'La Mujer', tribute poems to Angela Davis, and essays on Afro-Puerto Rican feminism in the Young Lords Party entered into the cultural mix of a changing revolutionary rhetoric. ${ }^{53}$

Accompanying the contestation of gender, race and culture was a renegotiation of 'identity' in the post-colonial world, which also struck at the US Left's remaking. The post-Bandung era brought new thinking on the relationship between race, class and subaltern subjectivity. Cuban intellectuals joined the ranks of Amílcar Cabral, Aimé Césaire and Frantz Fanon in theorising revolution and the post-colonial psyche. The Haitian exile and co-founder of Casa de las Américas, René Depestre, held that any durable alternative to Western assimilation meant a rejection of the tastes and values of the white bourgeoisie. Depestre warned against 'tio-tomism' (Uncle Tom-ism), and argued that identity was the basis of cultural regeneration of the developing world, something observable in the Cuban case as well. He maintained that Cuba was 'on the road to create the conditions of a true cultural mutation of human beings' that would 'carry the people

52 Angela Davis, Angela Davis: An Autobiograpby (New York, 1974), pp. 204, 216.

53 'Angela Davis habla desde la cárcel', Tricontinental (June 1971), pp. 17-23; Ernesto González Bernejo, 'Salvar a Angela', Tricontinental (February I972), pp. 28-31; René Depestre, 'Para celebrar la violencia de Angela Davis', Casa de las Américas (March-June I971), pp. 35-6; 'Los Young Lords', Tricontinental (Feb. I97I), pp. I 8-3 I ; Ema Herrera, 'Las Mujeres', Casa de las Américas (Sept.-Oct. 1970), pp. i 88-92; Ana Ramos, 'La mujer y la revolución en Cuba', Casa de las Américas (March-June i 971), pp. 56-72. 
towards a socio-cultural process of liberation'. This depended on the 'synthesis between social liberation and emancipation of the cultural faculties of man'. Depestre echoed Fanon when he argued that 'emancipation' equalled the transformation towards a post-colonial humanism, 'an identity founded on equality, dignity, and beauty of all men', as well as a 'process of cultural integration that unifies and improves each day the ethnic layers of a country and humanises interracial relations'. Political decolonisation meant decolonisation of the mind, the liberation of consciousness, deemed a necessary preface to social revolution. ${ }^{\mathbf{5 4}}$

This was the universalist framework in which Angela Davis posited her hope 'that more people - Black, Brown, Red, Yellow and white - might be inspired to join our growing community of struggle' ${ }^{55}$ She and others found Cuba a gateway to the broader post-colonial context that projected a multiracial and anti-capitalist humanism. Stokely Carmichael remembered being 'inspired by the humanistic idealism of [Cuba's] revolution' ${ }^{\mathbf{5 6}}$ The Cuban experience became a way for the US Left to challenge notions of racial, national and cultural singularity in favour of a universalism that did away with established social boundaries. The Venceremos Brigades exemplified a multiracial conglomerate that brought messages of Third World solidarity to the sugar fields of Cuba. ${ }^{57}$ At the heart of their campaign was the notion of reciprocity. 'We know', wrote one brigader, 'that in their struggles to liberate themselves, our revolutionary brothers and sisters in the third world are in fact liberating us'. Putting oneself in the other energised domestic campaigns in the United States as well as expanding the global struggle towards a common set of ideals that crossed national borders:

Colored people are waging a struggle everywhere in the world, just as they are within the United States. The realities of underdevelopment are reflected not only in Asia, Africa and Latin America but also in urban and rural areas of North America. We affirm that the common economic, cultural, and racial exploitation of our brothers and sisters of the Third World has put them in the vanguard of the struggle for liberation and development of mankind. ${ }^{58}$

Such identification produced a political self not confined to any one nation, race or culture. It hinted towards what is now commonly conceived of as a post-/trans-national, globalised world, where various national, racial and

54 René Depestre, 'Los fundamentos socioculturales de nuestra identidad', Casa de las Américas (January-February i 970), pp. 26-34.

55 Davis, Angela Davis, p. x. $\quad{ }_{56}$ Carmichael, Ready for Revolution, p. 584.

57 The Venceremos Brigades comprised some 1,500 students who travelled to Cuba in 1969 and 1970 to help with the ten million ton sugar harvest. The monumental goal rallied Cubans towards a nationalist purpose in honour of the tenth anniversary of the revolution. 'La zafra de los io millones' was to prove that Cuba's revolution was no longer an experiment and that economic advancement was possible through national collective will.

58 'The Political Purpose', pp. 8, i 4. 
cultural classifications are understood to be unstable, unbordered and polyvalent. This model of Left humanism, it could be argued, helps to explain why Che Guevara resonated so strongly among Third World nationalists, particularly in the Americas.

The focus on Che here is not to add another chapter to his 50-year hagiography but to submit some thoughts on why and how representations of Che sustained their discursive power in radical social movements. It can be suggested that his mass appeal in anti-establishment circles was enabled, in part, by the construction of Che as a stateless being who fought to erase divisions between the haves and have-nots. His thought and action promoted an Americanism writ large, America positioned as a terrain of shared struggle, something beyond and against US norms and desires. More formative in Che's thinking than Marx or Lenin, was José Martí and his pursuit of 'Our America'. Che envisioned himself fulfilling the ideals of Martí, such that the 'people's revolution' required a rejection of US-led initiatives like the Alliance for Progress and the Organisation of American States. The image of Che captured the imaginations of young radicals as one who embodied the perfect balance of theory and praxis talked about by Left evangelicals. His maxims influenced a generation that sought the overcoming of political alienation through direct action: revolutionary change through personal sacrifice. Che called violence the 'midwife of new societies', and like Frantz Fanon, he believed it an effective means towards achieving national liberation. ${ }^{59}$

And Che-ismo spread, his image cast in the minds (and on the would-be clothing) of supporters around the world. His death in 1967 became part of Cuba's revolutionary mystique, sparking campaigns to 'be like Che'. ${ }^{60}$ Che's political philosophy and theories of resistance appeared in marches in Los Angeles and Chicago and on the campuses of Columbia and Berkeley. Mark Rudd, a founding member of the Weathermen, believed Che to be an ideal model for his work. ${ }^{61}$ Rudd remembered becoming a 'foquista' while participating on a Students for a Democratic Society trip to Cuba in 1968. He was instantly struck by the 'cult of Che', and believed foco theory could be applied

60 José Llanusa, 'Hacer Hombres como el Che', Revolución y cultura, November 30, 1967, pp. I 8-20; 'Repercusión mundial de la muerte del Che,' Tricontinenal (December I967), pp. 6-20. For more on international remembrance of Che, see the January/February i 968 issue of Casa de las Américas.

61 The Weathermen (or Weather Underground) were a small group of former SDS student radicals who advocated extreme forms of dissent to protest the Vietnam War. The group appeared on the FBI's Most Wanted list and made national news in October 1969 during the Days of Rage campaign and in March 1970 when three members were accidentally killed while manufacturing bombs. 
to demonstrations and grassroots activism. ${ }^{62} \mathrm{He}$ and other college students could identify with Che's personal journey. They, too, were sons and daughters of middle and upper class professionals who yearned for a practical education in social change rather than classroom pedantry. The destruction of alienation and anxiety, it turned out, could be achieved by the national liberation of others.

Che's defiance of borders and boundaries bears relevance for further thinking on transnationalism. Recently, transnational studies have deemphasised the nation-state as the critical lens through which to view cultural activity, opting instead for paradigms that evaluate expressions beyond designations of 'Mexican', 'Haitian' or 'Chinese'. This has prompted a rejection of the 'comparative' framework in favour of models that limn cultural and political pursuits in their contested and hybrid forms as they cross national borders and defy essentialist classifications. ${ }^{63}$ Under the new rubric, the 'Third World' becomes a social location rather than a geographical coordinate. Many have pointed out that people can exist in First or Third World conditions irrespective of national origin. Regimes of privilege and repression operate within the broader global flow of people and capital, so that women of colour in the United States, for instance, can share political claims and existential predicaments with others of the Global South. ${ }^{64}$ This model privileges migratory experiences and is useful for displaying historical cases of racial solidarity and projects of global activism, as in the present discussion, when the US Third World Left redefined its humanistic enterprise within the international domain of political engagement. It was an ideological framework that depended on mutual identification between those who fought for Algerian independence and those who marched on Washington. Cuban politics concretised these alliances. Che Guevara stood as the quintessential figure in this formation, for to which 'nation' did Che belong? Argentine born, Cuban adopted, and one who spent the last years of his life fighting for nationalist movements in the Congo, Angola and Bolivia, Che was perceived as a borderless freedom fighter whose symbolic power lay in his statelessness. While he identified with the America of José Martí, his political vision encompassed the tricontinental.

62 Sina Rahmani, 'Anti-Imperialism and its Discontents: An Interview with Mark Rudd, Founding Member of the Weather Underground', Radical History Review, no. 95 (Spring 2006), pp. I $17-8$.

${ }^{63}$ Micol Seigel, 'Beyond Compare: Comparative Method after the Transnational Turn,' Radical History Review, vol. 9I (2005), pp. 62-90; Gilbert M. Joseph et al. (eds.), Close Encounters of Empire: Writing the Cultural History of U.S.-Latin American Relations (Durham, NC, 1998).

64 Chandra Mohanty, Feminism Without Borders: Decolonizing Theory, Practicing Solidarity (Durham, NC, 2003), pp. 44-8; M. Jacqui Alexander, Pedagogies of Crossing: Meditations on Feminism, Sexual Politics, Memory, and the Sacred (Durham, NC, 2005). 
But the case of Cuba also illustrates a point in this transnational hermeneutic that demands further thinking. While Cuba's tricontinentalism crafted a multiracial, multicultural and multinational community, it was at the same time a state discourse, which employed the transnational dynamic towards nationalist ends. If Che was a post-national figure, he was also a soldier who fought under the pretext of obtaining statehood for colonised or occupied populations. Nation-state status and national cohesion for Angolans, for instance, was to be the fruit of coalitional work. Moreover, Havana promoted a cartography of resistance that crossed borders and cultures in order to bolster its own project of nation-building. The nation-less/multi-national sensibilities of tricontinentalism were central to the sustenance of Cuba's preservation. Cuba had to bear an enormous political cross in the western hemisphere by maintaining its glacial anti-US position. In promoting itself as a Third World model to be followed, Cuban elites could serve the twin purposes of exporting their revolutionary programme while undergirding domestic consensus. Paradoxically, national cohesion in Cuba depended on the nationlessness of the tricontinental, so that Cubans could feel proud of their Cubanidad as their cultural and political reach extended well beyond their borders.

To be sure, Cubanidad continued to be constructed in opposition to monolithic notions of the United States, an insoluble antinomy that made ideas about identity, culture and politics still beholden to the historically constituted relationship between Cuba and its northern neighbour. The terms had changed, however; rather than aping US culture, Cuban citizens now officially opposed it. Anti-Yankee discourse became a matter of policy, the United States an enemy to be constantly combated. Nevertheless, battered and broken though it may have been, this cultural interconnectivity endured amid distinct political and social realities and under differing ideological assumptions. But it was the history of this interconnectivity that facilitated the cultural circuitry of radical politics. Tricontinentalism sculpted new expressions and directions in Left thinking in the United States as people, ideas and cultural texts continued to cross borders. It meant North American dissidents could participate in Third World liberation, spurred by the engine of Cuban political developments.

\section{Concluding Comments}

By way of conclusion, it is worth pointing out some of the problems associated with this brand of progressive work. Doubts regarding Cuba's revolutionary veracity have abounded, with revolution now viewed more as a commodity than a tenable political solution. Early on, Mark Rudd lamented that Che's celebrity status diluted his political power. Che's iconographic 
status unveiled the tension between Left political praxis and counter-cultural faddism, when Che could be reduced to what Rudd called a 'revolutionary romantic'. The Cuban revolution has lived its later years as both revolutionary promise and postmodern spectacle, something determined by geopolitics and global markets. ${ }^{65}$ The idea of revolution still poses multiple and contradictory imaginings that draw debates over cultural and political appropriation, and remain as problematic today for grassroots organising as they did for New Left members in the ig6os.

Furthermore, as with today's global movements, the Left's transnational work was also beset by the very divisions they sought to erase. People who lived in the First World could claim identification with those in the Third, but the converse was not always true. It became problematic to compare even low-income college students in the United States with the billions who lived a daily subaltern existence mired in extreme poverty, disease and hunger. US Leftists maintained a privileged position when they understood their social predicaments to be commensurate with those in poor nations. The realities of the Third World, therefore, tested the limits of this discourse, for assuming a shared experience between inhabitants of New York City and New Delhi, or between black and white, also produced a range of cynical denials and coalitional backlash.

Despite such fissures, transnational social causes continue to evolve, enabled by an ever increasing network of global communication, capital and populations in transit. There remain human concerns that cannot be solved in national frameworks alone, and people continue to identify with problems and programmes that break standard classificatory systems which have historically governed our modern age. One of our tasks, therefore, is to find new critical frameworks to describe and historicise such interactions among disparate groups and to engage with their myriad ideological and cultural proclivities, something beyond the epistemological constraints that still define and determine Western/Northern scholarship. The Left's romance with the Cuban revolution offers a case study of how political events from afar become domesticated and understood in local terms. Today, the crosscurrent portrayals of revolution continue to take shape in a variety of contexts, from Venezuelan president, Hugo Chávez, brandishing a Cuban baseball hat in front of thousands of supporters, to images of Che and Fidel peppered across dorm room walls around the United States. The Cuban revolution still inspires kitsch, ire and inspiration, making an appraisal of its significance especially timely in contemporary Left politics. ${ }^{66}$

65 Francisco Portela, 'Entrevista a Mark Rudd', Revolución y cultura, I 5 August I 968, pp. I I 3-7.

${ }^{66}$ Marc Lacey, 'A Communist He Was, but Today, Che Sells', New York. Times, 9 Oct. 2007 , p. 4. 